\title{
DYNAMICS THE RR FOR EVALUATION OF INTENSITY OF PHYSICAL ACTIVITY UNTO PREGNANT WOMEN
}

\author{
Irina Nesheva \\ National Sports Academy „V. Levsski „
}

Keywords: Gymnastics, pregnancy, changes, arterial blood pressure

\section{Introduction}

Pregnancy is normal but extremly complex biological process, that has a profound influence over the regulatory functions of a woman (Melzer, K., Schutz, Y., Boulvain, M. \& Kayser, B. 2010a; Генчева, Н., Д. Попова \& М. Ангелчева 2007).

The physiological and hormonal changes throughout the pregnancy are unique for one woman's life. The hormones of pregnancy sometimes suddenly affect upon the tonus of the blood vessels by reduction of the arterial pressure (Mcmurray, R. G., Katz, V. L., Berry, M. J. \& Cefalo, R. C. 1988; Tortora, J. G. 1987; Гаврийски, В., Д. Стефанова, Е. Киселкова \& Бичев, К. 2005). Putting into practice a systematic physical exercises stabilizes the body of the future mother, also it has a favorable affect to the adaptation for this unique statement, it supports the pregnant woman functional reserve (Baciuk, E. P., Pereira, R. I., Cecatti, J. G., Braga, A. F. \& Cavalcante, S. R. 2008; Borodulin, K. M., Evenson, K. R., Wen, F., Herring, A. H. \& Benson, A. M. 2008; Broso, P. \& Buffetti, G. 1993; Hegaard, H. K., Damm, P., Nielsen, B. B. \& Pedersen, B. K. 2006; Jarski, R. W. \& Trippett, D. L. 1990; Гаврийски B., Д. Стефанова, Е. Киселкова \& Бичев, К. 2005; Георгиев, М. 1999). A main component of our methodology (in field conditions) is the implementation of functional control for the assessment of the intensity of applied gymnastic exercises by the Nesheva Program for pregnant women and the objective method used is the monitoring of arterial blood pressure. Gymnastics with its diverse variations and attractive disciplines has its considerably important role for the preparation of a pregnant woman. The gymnastic tools, precisely selected, have a general/ holistic as well as one good, broad impact for the future delivery (Нешева, И. 2010).

Good alternative would be Recreative practices during the pregnancy. They can be regarded, as defined by (Димитрова, Б. 2009) in her research “... developing a polyvalent SPA culture...". It is important by (Димитрова Б. 2012) to”...discuss issues with remedial influence like the physical activity in aquatic environment and the immediate connection with the improvement of quality of life and health status for the participants ...". Great growth rates operation of services with qualified personnel certified through educational programs (Димитрова Б. and I. Donev 2006; Dimitrova, В. 2014), the quality services for pregnant women, required staff with fellowships, training seminars or received certified competencies (Димитрова Б. 2011; Dimitrova, B. 2014).

Arterial blood pressure decreases in early pregnancy, then slightly increases to pre-natal. In the second trimester, the heart rate of the pregnant woman at rest is faster, the effect of which is increased systolic volume of the heart. Hormones of pregnancy sometimes suddenly affect the blood vessel tone with lower blood pressure. The heart volume is increased by $30-40 \%$ (Tortora, 1987), due to increased metabolism and increased maternal blood flow to the placenta. The aim of our report is to study the influence of gymnastics on pregnant women on the functional reserve. And the tasks to accomplish the goal are:

1. Investigate the dynamics of arterial blood pressure in training pregnant women to assess the intensity of gymnastic activities. 2. Reporting and control of the functional indicator (RR):

- arterial blood pressure (Systolic pressure RRs, diastolic pressure - RRd) at baseline

(RRs_I, RRd_I) and final study (RRs_F, RRd_F);

- arterial blood pressure before and after a separate gymnastic

(RRspre, RRdpre, RRspost, RRdpost). 


\section{Methodology}

A main component of our methodology is the implementation of functional control for the assessment of the intensity of applied gymnastic exercises by the Nesheva Program for pregnant women and the objective method used is the monitoring of arterial blood pressure. To evaluate the effect of the Program on the cardiorespiratory parameters, a one-factor dispersion analysis was applied to the associated samples (ANOVA with repeated measures).

The Tester System Temeo (manufactured by SST, Bulgaria certified as a telemedicine device, TIV model $2 \mathrm{~A}$ under TIV with the number 4422111384068-001) has registered a total of 47 pregnant women records during six gymnastic classes. The device includes a belt with a chip (figure 1 and 2) that is placed under the chest and the Doppler device is placed on one hand. The average duration of the recording is 50-60 minutes with direct visualization on the internet (Petrov et al., 2012; Нешева, И. 2014).
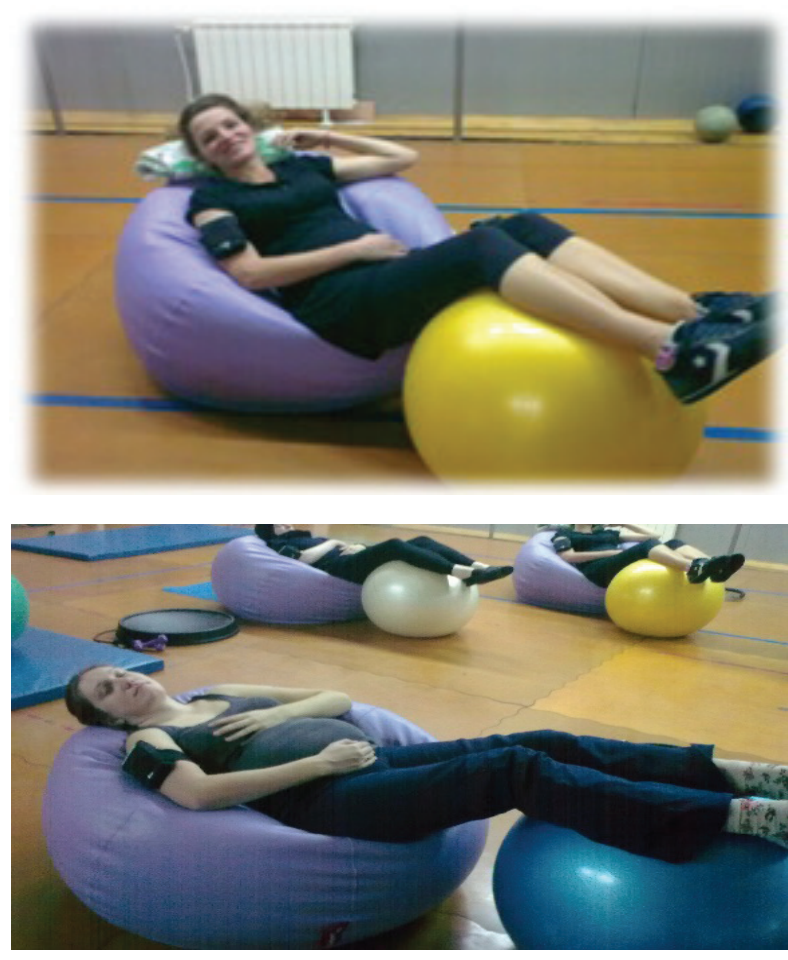

Figure 1-2 RR study at motor complex and relaxation at the end of the training

\section{RESULTS}

Table 1 presents the results of descriptive statistics (Mean \pm SD) of circulatory performance of one hundred pregnant women during periodic inclu- sion in the Gymnastics Program.

Table 1. Values (Mean \pm SD) of the arterial blood pressure (RRs, RRd) functionalities upon inclusion in the Program.

\begin{tabular}{|l|l|l|}
\hline \multicolumn{1}{|c|}{ INDICATORS } & \multicolumn{1}{|c|}{ N } & \multicolumn{1}{c|}{ Mean \pm SD } \\
\hline RRs $[\mathrm{mm} \mathrm{Hg}]$ Systolic blood pressure & 100 & $109.5 \pm 13.68$ \\
\hline RRd $[\mathrm{mm} \mathrm{Hg}]$ Diastolic blood pressure & 100 & $69.1 \pm 8.36$ \\
\hline
\end{tabular}

The results obtained in relative resting conditions for RRs and RRd indicate that systolic pressure is around the lower limit and diastolic pressure is the mean value for the normal.

In the experiment, an example was a study of 6 women (3rd trimester) with normal pregnancy (age $29 \pm 1.84$ years, height $165 \pm 10.01 \mathrm{~cm}$ ) with an average of 10-12 exercises from the gymnastic program.

The cardiac responses RRs, RRd measured before (pre) and immediately after (post) specific gymnastic activity (table 2).

Table 2. Variation analysis (Mean $\pm \mathrm{SD}$ ) of cardiac responses

\begin{tabular}{|l|l|c|}
\hline \multicolumn{1}{|c|}{ INDICATORS } & MEAN & SD \\
\hline $\begin{array}{l}\text { RRs pre [mm Hg] - Systolic blood pressure } \\
\text { before exercise }\end{array}$ & 101,67 & 9,31 \\
\hline $\begin{array}{l}\text { RRs post [mm Hg] - Systolic blood pressure } \\
\text { after exercise }\end{array}$ & 98,17 & 7,49 \\
\hline $\begin{array}{l}\text { RRd pre [mm Hg] - Diastolic blood pressure } \\
\text { before exercise }\end{array}$ & 61,00 & 4,69 \\
\hline $\begin{array}{l}\text { RRd post [mm Hg] - Diastolic blood pres- } \\
\text { sure after exercise }\end{array}$ & 59,33 & 5,12 \\
\hline
\end{tabular}

The comparison between the measures measured before and after the gymnastic occupation showed that only diastolic pressure values $(\mathrm{p}<0.05)$ were significantly different. Before working diastolic pressure correlates only with diastolic pressure after gymnastics. The systolic pressure is slightly lower compared to the reference values for women, most likely related to pregnancy. Diastolic pressure is found to be within the limit of normal.

\section{Conclusions}

1. The indicators of the circulation in the relative rest of the pregnant women when entering the gymnastics program are within the limits of the norm.

2. Upon completion of the Program, improved control of arterial blood pressure is established. 
3. The impact of the individual activities of the Nesheva Program on Pregnant Women is characterized by a good recovery of circulatory performance.

\section{References}

Baciuk, E. P., Pereira, R. I., Cecatti, J. G., Braga, A. F. \& Cavalcante, S. R. (2008), Water aerobics in pregnancy: Cardiovascular response, labor and neonatal outcomes. Reprod Health, 5, 10

Borodulin, K. M., Evenson, K. R., Wen, F., Herring, A. H. \& Benson, A. M. (2008), Physical activity patterns during pregnancy. Med Sci Sports Exerc, 40, 1901-8

Broso, P. \& Buffetti, G. (1993), Sports and pregnancy. Minerva Ginecol, 45, 191-7

Dimitrova, B. (2014), The enotherapy as an effective financial instrument for the wine tourism. International Scientific Conference for Tourism "SPA and wine"- part of the Culture corridor - cultural routes. Blagoevgrad. Faculty of Economy, Tourism department. SW University. Proceedings, 55-61.

Hegaard, H. K., Damm, P., Nielsen, B. B. \& Pedersen, B. K. (2006), Pregnancy and recreational physical activity. Ugeskr Laeger, 168, 564-6

Jarski, R. W. \& Trippett, D. L. (1990), The risks and benefits of exercise during pregnancy. J Fam Pract, 30, 185-9 Mcmurray, R. G., Katz, V. L., Berry, M. J. \& Cefalo, R. C. (1988), Cardiovascular responses of pregnant women during aerobic exercise in water: a longitudinal study. Int J Sports Med, 9, 443-7

Melzer, K., Schutz, Y., Boulvain, M. \& Kayser, B. (2010a), Physical activity and pregnancy: cardiovascular adaptations, recommendations and pregnancy outcomes. Sports Med, 40, 493-507

Petrov L., P., Atanasov, N., Zaekov, A., Alexandrova, Z., Zsheliaskova-Koynova \& Achkakanov (2012), Physiological and non-invasive biochemical indexes in a model of emotional stress in shooters. Medical University, 44 (1), 55-58

Tortora, J. G. (1987), Principles of Anatomynand Psysi- ology, New York, Harper \& Row

Гаврийски, В., Д. Стефанова, Е. Киселкова \& Бичев, К. (2005), Физиология на човека с физиология на спорта I част, [Physiology of human with physiology of sport I part] С., Изд. Нови знания

Гаврийски В., Д. Стефанова, Е. Киселкова \& Бичев, К. (2005), Физиология на човека с физиология на спорта II част, [Physiology of human with physiology of sport II part] С., Изд. Нови знания

Генчева, Н., Д. Попова \& М. Ангелчева (2007), Методика на фит-бол гимнастика по време на бременността, [Methodology of fit-ball gymnastics gymnastics in during pregnancy], Спорт \& Наука, C., бр.2, 77-83

Георгиев, М. (1999), кн. Функционални състояния [Functional states] C.

Димитрова, Б., И. Донев (2006), Плувни спортове в училище. Монография. [Swimming sports in school. In Bulgarian] София: Издателство Авангард Прима

Димитрова, Б. (2009), SPA култура и аква практики. Учебник за ОКС „Магистьт“. [SPA culture and aqua practices. In Bulgarian.] София: Издателство Авангард Прима

Димитрова, Б., Н. Деде (2011), Акваспининг като антистресова превенция на здравето. Трета международна научна конференция: Оптимизация и иновации в учебно-тренировъчния процес. [Aqua spinning as anti-stressing health prevention. 3th International Scientific conference: Optimization and innovation in educational training process.] Department of Physical education and sport, Sofia University "St. Kl. Ohridski. Сборник доклади, 2011, 146-153

Димитрова, Б. (2012), Аква практики [Aqua practices. In Bulgarian] София: Издателство Авангард Прима

Нешева, И. (2010), Примерен модел на двигателна активност за жени с нормална бременност [An exemplary model of locomotor activity for women with normal pregnancy], НCA, C., I част, сб. „V международен научен конгрес ССА"

Нешева, И. (2014), Дисертация. [Dissertation] www. nesheva.eu 